\title{
Provisional guidelines for fall lifting for frozen overwinter storage of nursery stock
}

\section{R. E. Mullin and J. D. Parker}

Forest Research Branch,

Ontario Ministry of Natural Resources

\begin{abstract}
An experiment was started in the fall of 1972 to study the effects of the date of fall lifting on the post-planting performance of overwinter stored white spruce and jack pine. Storage at two temperatures was used, $0^{\circ} \mathrm{F}\left(-18^{\circ} \mathrm{C}\right)$ and $26^{\circ} \mathrm{F}$ $\left(-4^{\circ} \mathrm{C}\right)$, with the former a failure, the latter successful. Spring planting indicated that "too early" outplanting is possible. Stored white spruce may be used to extend the planting season into late spring, but not jack pine.

Degree-Hardening-Days, D-H-D, i.e. cumulative daily differences below $50^{\circ} \mathrm{F}$ from soil temperatures at $15 \mathrm{~cm}$ depth, is suggested as a possible criterion of stock readiness for storage. White spruce was about 200 D-H-D and jack pine about 375. By inferences from other experiments white pine is about 225 D-H-D and red pine about 300 .
\end{abstract}

\section{Résumé}

Un essai débuté à l'automne 1972 consistait à tenir compte des effets de la date du repiquage automnal de l'épinette blanche et du pin gris alors conservés en chambre froide durant l'hiver et de leur rendement en plantation le printemps suivant. Les températures fixées durant cette conservation furent respectivement de $0^{\circ} \mathrm{F}$ $\left(-18^{\circ} \mathrm{C}\right)$ et de $26^{\circ} \mathrm{F}\left(-4^{\circ} \mathrm{C}\right)$; alors que la première se solda par une perte totale, la seconde se traduisit par une réussite. La plantation printanière montra qu'une telle plantation "trop précoce" est possible. De plus, l'essai démontra que la conservation de l'épinette blanche en chambre froide permet d'allonger la saison des plantations tard le printemps, ce qui n'est pas vrai pour le pin gris.

L'auteur suggère un nombre de degrés-jours pour la lignification "D-H-D", i.e. les différences cumulatives journalières au-dessous de $50^{\circ} \mathrm{F}$ au moyen des températures du sol établies à une profondeur de $15 \mathrm{~cm}$, en tant que critère possible de l'état du matériel prêt à la conservation. L'épinette blanche atteignait quelque 200 degrés-jours pour la lignification, le pin gris, 375 . En comparant avec d'autres essais, le pin blanc et le pin rouge atteignait quelque 225 et 300 de cette même mesure.

\section{Introduction}

Overwinter storage of nursery stock has many advantages to offer the nurseryman and tree planter. In recent years there has been (in northern climates) a shift from cold storage (above freezing temperatures) to frozen storage (Mullin and Bunting 1970; Nyland 1974a). However, frozen storage losses have occurred, and may be due to improper timing of the fall lift for storage.

The nurseryman must be able to determine whether his trees are sufficiently hardened-off for lifting and storage. Nyland (1974b) suggested that the start of spruce lifting should be "when the tips of major roots on pine species shorten to $1 / 2 "$, and the soil temperature drops to $50^{\circ}$ for several days. This is difficult due to variation of root tip development within and between pine species and fluctuations in soil temperature. Another way to determine frost hardiness development may be through the measurement of electrical impedence of trees (Glerum 1974).

An earlier study which examined the effects of weekly lifts in the fall, for frozen storage, showed that white spruce (Picea glauca Moench. (Voss)) was ready for lifting first, white pine (Pinus strobus L.) next, and red pine (Pinus resinosa Ait.) last (Mullin 1974a).

\section{Procedure}

This study was started in the fall of 1972 at the Midhurst Nursery to determine the effects of the date of fall lifting and frozen overwinter storage on subsequent survival and growth of the trees, and to try to relate soil temperatures in the root zone at the time of lifting to the results. There were five weekly lifts from October 19 to November 16, when the lifts had to be curtailed due to weather conditions. The trees were randomly selected from beds of 3-0 white spruce and 2- 0 jack pine. All of the stock originated from and was outplanted in seed zone 6E (Hills 1960).

When lifted, the trees were packed in regular Kraft-polyethylene bags. For each species there were three bags of 300 trees per lift, one for storage at $26^{\circ} \mathrm{F}\left(-4^{\circ} \mathrm{C}\right)$, one at $0^{\circ} \mathrm{F}\left(-18^{\circ}\right)$, and one for laboratory sampling of top-length, root length, stem diameter, oven-dry weight, and toproot ratio (Table 1 ). The stock was representative 
Table 1. Average seedling characteristics for trees lifted in Fall 1972, October 19 and 26, November 3, 9 and 16. Random sample unit of 50 trees

\begin{tabular}{|c|c|c|c|c|}
\hline & $\begin{array}{l}\text { Top }{ }^{1} \\
\text { length } \\
\text { (cm) }\end{array}$ & $\underset{(\mathrm{cm})}{\text { Stem }^{2}}$ & $\begin{array}{l}\text { Oven-dry }{ }^{3} \\
\text { weight } \\
\text { (g) }\end{array}$ & $\begin{array}{c}\text { Top } / \text { root }^{4} \\
\text { weight } \\
\text { ratio }\end{array}$ \\
\hline 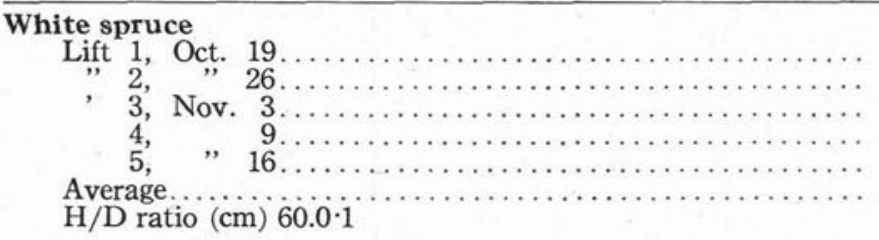 & $\begin{array}{l}27.4 \\
26.5 \\
27.3 \\
27.5 \\
27.6 \\
27.3\end{array}$ & $\begin{array}{l}0.48 \\
0.42 \\
0.46 \\
0.47 \\
0.45 \\
0.46\end{array}$ & $\begin{array}{l}5.81 \\
4.33 \\
5.42 \\
6.54 \\
5.60 \\
5.54\end{array}$ & $\begin{array}{l}4.97 \\
5.60 \\
4.84 \\
5.35 \\
4.82 \\
5.11\end{array}$ \\
\hline 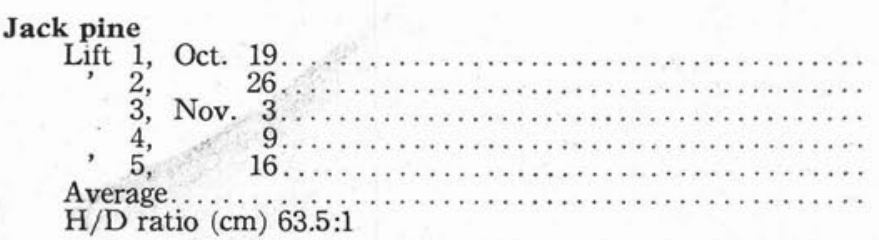 & $\begin{array}{l}31.8 \\
35.5 \\
32.2 \\
31.9 \\
32.3 \\
33.0\end{array}$ & $\begin{array}{l}0.52 \\
0.51 \\
0.48 \\
0.57 \\
0.50 \\
0.52\end{array}$ & $\begin{array}{l}6.27 \\
6.27 \\
5.50 \\
8.25 \\
6.55 \\
6.57\end{array}$ & $\begin{array}{l}6.90 \\
8.14 \\
9.06 \\
6.91 \\
7.38 \\
7.68\end{array}$ \\
\hline
\end{tabular}

${ }^{1}$ Root collar to base of terminal bud.

${ }^{2}$ At approximately $1 \mathrm{~cm}$ above root collar.

324 hours at $105^{\circ} \mathrm{C}$.

${ }^{4}$ By oven-dry weight.

of regular shipping stock but showing excessive top-root ratios (Armson and Carman 1961). Since nearly all trees stored at $0^{\circ} \mathrm{F}\left(-18^{\circ} \mathrm{C}\right)$ died, this part of the experiment will not be discussed further. Field measurements at time of lifting included air temperature, soil temperature at $15 \mathrm{~cm}$ depth, and relative humidity.

In the spring of 1973, randomized and replicated plantings of the stored stock were made at Midhurst in comparison with freshly-lifted stock (controls) from the same beds. Air and soil temperatures, and relative humidity were recorded. The planting site is a level loamy sand, stone free, of low natural fertility and low moisture regime. The jack pine was planted April 9, May 9 and June 11 (Plants 1, 2 and 3), 1500 trees at each time. The white spruce was similarly planted April 12 , May 17 and June 14 . All planting was by wedge method in shallow furrows, in a sparse sod field.

Survival and terminal lengths (current year's growth) were obtained at the end of the second growing season. All data were processed by analyses of variance, separately by species and planting times.

\section{Results}

\section{Storage of White Spruce}

The results for white spruce are summarized in Table 2. The freshly-lifted, unstored controls gave good results at regular planting, poor results at the early planting, and intermediate results from planting in mid-June. This may indicate that freshly-lifted white spruce may give slightly reduced survival from late planting.

Of the stored trees, the early planting give equally poor results. In the regular and late plantings, however, the date of lifting had some significant effects on growth and survival with the third and fourth liftings showing favourable sur- vival. The results in terms of lifting dates are not clear, however; there are some mixed trends and the poor survival of lift 5 appears anomalous.

The results show that either freshly-dug or stored white spruce, if lifted at the proper time, will give comparable results when used to extend planting into mid-June.

\section{Storage of Jack Pine}

The results for jack pine are summarized in Table 3 . In the unstored controls the early planting was satisfactory, as was the regular planting, whereas the late planting was obviously a failure.

In the overwinter-stored stock the early planting was poor. The results for the regular planting showed that the last lifting, 5, was reasonably satisfactory but still lagged about $14 \%$ behind the freshly-dug stock in terms of survival. In the late planting, the stored stock from the late lifting was better than freshly-dug stock.

The results show clearly the need for late fall lifting of jack pine if intended for storage. They also indicate that freshly-dug spring-lifted trees may give better results for early and mid-season planting, whereas stored stock may give better results for late planting (although well below the results of spring lifting and mid-season planting of unstored stock).

\section{Timing the Fall Lifting for Storage (Degree-Hardening-Days)}

The results of this experiment indicate that white spruce is ready for frozen storage some weeks before jack pine in Southern Ontario. Previous work has shown that white pine and red pine may be intermediate, and in that order (Mullin and Parker 1974; Mullin 1974a). It would be of some help to the nurserymen if a simple criterion for storage readiness, by species, could be established.

The cumulative effect of low temperatures 


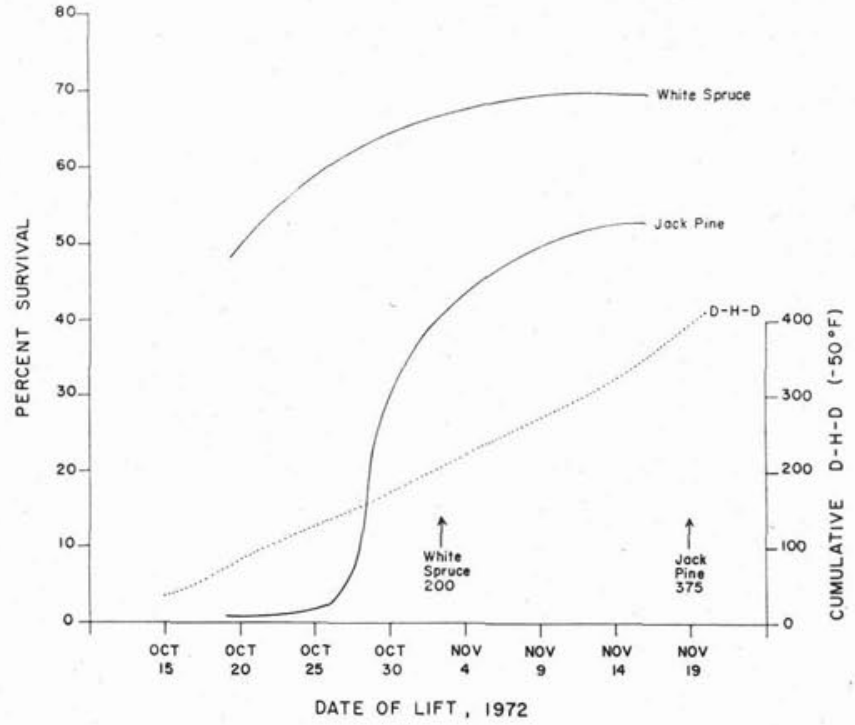

Figure 1. Second year survival percentages by dates of fall lifting for overwinter storage and cumulative Degree - Hardening - Days. over a period of time such as "below $40^{\circ} \mathrm{F}$ for 20-30 days" (Nyland 1974b), might be expressed in a simple formula. A negative degree-hardeningdays, D-H-D (from degree-days, Zasada 1973) with a basis of $50^{\circ} \mathrm{F}$ (Nyland 1974b), was prepared daily of the differences between $50^{\circ} \mathrm{F}$ and the daily minimum for soil temperature at $15 \mathrm{~cm}$ depth.

The results of a summary done this way for 1972 are plotted in Fig. 1, showing the steady upward progression of D-H-D. Freehand curves (to reduce effects of the particular weather conditions on the day of lifting) are plotted of average survival for white spruce (plants 2 and 3 ) and jack pine (plants 1,2 and 3). It is of interest to note that the readiness for storage builds up gradually in white spruce whereas it rises rather abruptly in jack pine. It can be inferred that white spruce is ready for storage at about 200 D-H-D and jack pine at about 375 . From a previous experiment (Mullin 1974a) tentative D-H-D can be suggested of about 225 for white pine and 300 for red pine.

Table 2. WHITE SPRUCE. Second_year_survival percentages and terminal lengths (current year's growth) for white spruce by lifting and planting dates

\begin{tabular}{|c|c|c|c|c|c|c|}
\hline & \multicolumn{2}{|c|}{$\begin{array}{l}\text { Plant } 1 \\
\text { Apr. 12 }\end{array}$} & \multicolumn{2}{|c|}{$\begin{array}{l}\text { Plant } 2 \\
\text { Miay } 17\end{array}$} & \multicolumn{2}{|c|}{$\begin{array}{l}\text { Plant } 3 \\
\text { June } 14\end{array}$} \\
\hline & $\underset{\%}{\text { Surv. }}$ & $\begin{array}{c}\text { Term. } \\
\text { cm }\end{array}$ & Surv. & $\begin{array}{c}\text { Term. } \\
\text { cm }\end{array}$ & Surv. & $\begin{array}{c}\text { Term } \\
\text { cm }\end{array}$ \\
\hline 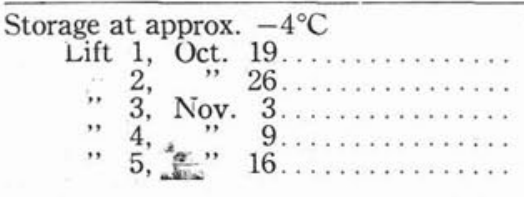 & $\begin{array}{l}50 \\
42 \\
51 \\
66 \\
60\end{array}$ & $\begin{array}{l}6.4 \mathrm{a}^{1} \\
5.5 \mathrm{a} \\
6.8 \mathrm{ab} \\
8.0 \mathrm{bc} \\
8.4 \mathrm{c}\end{array}$ & $\begin{array}{l}54 \\
55 \\
72 \\
60 \\
56\end{array}$ & $\begin{array}{l}6.9 \mathrm{a} \\
7.3 \mathrm{ab} \\
8.3 \mathrm{~b} \\
8.0 \mathrm{~b} \\
8.4 \mathrm{~b}\end{array}$ & $\begin{array}{l}57 a b \\
52 a \\
71 b c \\
76 c \\
53 a\end{array}$ & $\begin{array}{l}8.1 \mathrm{bc} \\
6.3 \mathrm{a} \\
7.0 \mathrm{a} \\
9.7 \mathrm{c} \\
9.2 \mathrm{c}\end{array}$ \\
\hline $\begin{array}{l}\text { Control } \\
\quad \text { Spring lifted } \ldots \ldots \ldots \ldots \ldots \ldots \ldots\end{array}$ & $\begin{array}{l}65 \\
\text { NS }\end{array}$ & $\underset{* *}{6.5 a}$ & $\begin{array}{l}82 \\
\text { NS }\end{array}$ & $6.6 \mathrm{a}$ & $74 \mathrm{c}$ & $\underset{*}{7.6 \mathrm{ab}}$ \\
\hline
\end{tabular}

NS = not significant.

* $\quad=$ significant at $5.0 \%$ level.

** = significant at $1.0 \%$ level

${ }^{1}$ Figures within a column followed by same letter are not significantly different by range tests.

Table 3. Jack pine. Second year survival percentages and terminal lengths (current year's growth) for jack pine, by lifting and planting dates

\begin{tabular}{|c|c|c|c|c|c|c|}
\hline \multirow{2}{*}{ 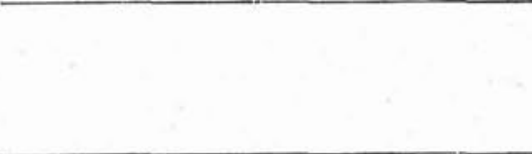 } & \multicolumn{2}{|c|}{$\begin{array}{r}\text { Plant } 1 \\
\text { Apr. } 9\end{array}$} & \multicolumn{2}{|c|}{$\begin{array}{r}\text { Plant } 2 \\
\text { May } 9\end{array}$} & \multicolumn{2}{|c|}{$\begin{array}{l}\text { Plant } 3 \\
\text { June } 11\end{array}$} \\
\hline & Surv. & $\begin{array}{c}\text { Term. } \\
\text { cm }\end{array}$ & Surv. & $\begin{array}{c}\text { Term. } \\
\text { cm }\end{array}$ & Surv. & $\begin{array}{c}\text { Term. } \\
\text { cm }\end{array}$ \\
\hline 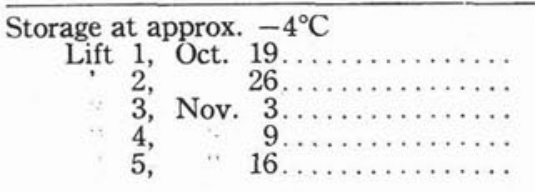 & $\begin{array}{l}1 \mathrm{a}^{1} \\
2 \mathrm{a} \\
40 \mathrm{~b} \\
41 \mathrm{~b} \\
53 \mathrm{c}\end{array}$ & $\begin{array}{l}29.5 \mathrm{bc} \\
32.5 \mathrm{c} \\
21.9 \mathrm{a} \\
23.7 \mathrm{ab} \\
32.1 \mathrm{c}\end{array}$ & $\begin{array}{c}0 \mathrm{a} \\
7 \mathrm{a} \\
45 \mathrm{~b} \\
65 \mathrm{bc} \\
72 \mathrm{bc}\end{array}$ & $\begin{array}{r}0 \mathrm{a} \\
26.1 \mathrm{~b} \\
31.4 \mathrm{c} \\
34.5 \mathrm{c} \\
35.2 \mathrm{c}\end{array}$ & $\begin{array}{r}6 \mathrm{a} \\
3 \mathrm{a} \\
29 \mathrm{~b} \\
50 \mathrm{~b} \\
76 \mathrm{c}\end{array}$ & $\begin{array}{l}23.4 \mathrm{ab} \\
21.3 \mathrm{a} \\
25.6 \mathrm{~b} \\
25.9 \mathrm{~b} \\
27.6 \mathrm{~b}\end{array}$ \\
\hline $\begin{array}{l}\text { Control } \\
\quad \text { Spring lifted } . \ldots \ldots \ldots \ldots \ldots \ldots\end{array}$ & $\begin{array}{l}85 \mathrm{~d} \\
* * *\end{array}$ & ${ }_{* *}^{33.8 \mathrm{c}}$ & $\begin{array}{l}86 \mathrm{c} \\
* * *\end{array}$ & $\underset{* *}{33.6 \mathrm{c}}$ & $\underset{* * *}{48 \mathrm{~b}}$ & ${ }_{*}^{17.6 a}$ \\
\hline
\end{tabular}

NS $=$ not significant.

* $\quad=$ significant at $5.0 \%$ level.

** $\quad=$ significant at $1.0 \%$ level.

*** $=$ significant at $0.1 \%$ level.

${ }^{1}$ Figures within a column followed by same letter are not significantly different by range tests

24 February 1976 The Forestry Chronicle 


\section{Discussion}

It is realized that further testing and refinement of D-H-D is necessary, and that growth must be the final consideration. Differences by nurseries, and differences within species dependant upon seed source, can be expected to occur. The nurseryman can easily monitor D-H-D by inserting the probe of a 7-day recording thermometer horizontally at $15 \mathrm{~cm}$ depth in seedbed or transplant lines. At the end of each week the D-H-D can be accumulated from differences below $50^{\circ} \mathrm{F}$ (daily low). He can then record the D-H-D for each lot of stock placed in storage and in due time relate this to feedback of survival and growth results from the field planting of the stock, and from his own planting-test plots.

There is in Table 2 an indication that the first planting was too early for both stored and fresh white spruce. This was not true of the fresh jack pine, indicating species differences. It has also been observed that red pine may suffer from too early planting (Mullin 1974b). The reduction in survival may be due to dessication in cold soil as soil temperature was $1^{\circ}-2^{\circ}$ at planting and water movement is known to be slow at these temperatures (Hermann 1965; Sutton 1969). It is known that differences occur between species in relation to soil temperature and resumption of root activity (Hilton and Mason 1971). Tentatively it is suggested that neither spruce nor red pine should be planted before soil temperatures reach $5^{\circ} \mathrm{C}$ (Lyr and Hoffman 1967).

The survival rates for stored and unstored white spruce in this experiment (Table 2) are below that of other studies, e.g. $85 \%$ (Mullin and Parker 1974) and 92\% (Mullin and Bunting 1972). This may be partly due to the quality of the stock as the top-root ratio (Table 1) was well above the maximum of the working range given for 3-0 white spruce in Ontario nurseries; 2.5 to 4.5:1 (Armson and Carman 1961), and was in the "top-heavy" class of Stoeckeler and Jones (1957). Similarly the maximum survival rate of $76 \%$ (Table 3) for stored jack pine does not indicate successful overwinter storage. Again this is probably due in part to poor top-root ratio (Table 1), almost twice the acceptable working range of Armson and Carman (1961), and in the "very top-heavy" class of Stoeckeler and Jones (1957).

\section{References}

Armson, K.A. and R.D. Carman. 1961. Manual of forest tree nursery soil management. Ontario Dep. Lands Forest., Timber Branch. Unnumbered. $74 \mathrm{p}$.

Glerum, C. 1974. The use of electrical impedance in monitoring nursery stock for frost hardiness. In Nurserymen's Meeting, Midhurst, June 1972. Ontario Min. Natur. Resources. Unnumbered. 59-63.

Hermann, R.K. 1965. Survival of planted ponderosa pine in southern Oregon. Forest Res. Lab., Oregon State Univ., Corvallis. Res. Paper 2. 32 p.

Hills, G.A. 1960. Regional site research. For. Chron. 36(4): 401-423.

Hilton, R.J. and G. F. Mason. 1971. Responses of mugho pine roots to soil temperature and of Bolleana poplar roots to light. Hortscience. 6(1):43-45.

Lyr, H. and G. Hoffmann. 1967. Growth rates and growth periodicity of tree roots. In Int. Rev. For. Res. Vol 2: 181-236.

Mullin, R.E. 1974a. Cold storage of nursery stock in Ontario. In Nurserymen's meeting, Midhurst, June 1972. Ontario Min. Natural Resources. Unnumbered: 30-53.

Mullin, R.E. 1974b. Effects of root exposure on establishment and growth of outplanted trees. In II International Symp. of Ecology and Physiology of Root Growth. Akademie Verlag, Berlin: 229-242.

Mullin, R.E. and W.R. Bunting. 1970. Frozen overwinter storage for red pine. U.S. Forest. Serv., Tree Planters' Notes 21(4): 8-9.

Mullin, R.E. and W.R. Bunting. 1972. Refrigerated overwinter storage of nursery stock. J. For. 70(6)::354-358.

Mullin, R.E. and J.D. Parker. 1974. Bales versus polybags in cold and frozen overwinter storage of nursery stock. Can. J. For. Res. (4(2):254-258.

Nyland, R.D. 1974a. Sub-freezing temperatures control storage molding. State Univ. New York; Coll. Environmental Sci. and Forest., Syracuse. Applied Forest Res. Inst. AFRI Res. Note 11. 3 p.

Nyland, R.D. 1974b. Fall lifting for over-winter cold storage of conifers. State Univ. New York; Coll. Environmental Sci. and Forest., Syracuse. Applied Forest Res. Inst. AFRI Res. Rep. 22. 5 p.

Stoeckeler, J.H. and G.W. Jones. 1957. Forest Nursery practice in the Lake States. U.S. For. Serv., Agric. Handbook 110. $124 \mathrm{p}$.

Sutton, R.F. 1969. Form and development of conifer root systems. Commonwealth Forest. Bur., Tech. Commun. 7 . $131 \mathrm{p}$.

Zasada, J.C. 1973. Effect of cone storage method and collection date on Alaskan white spruce (Picea glauca) seed quality. In International Symp. on Seed Processing. Bergen, Norway. IUFRO. 10 p.

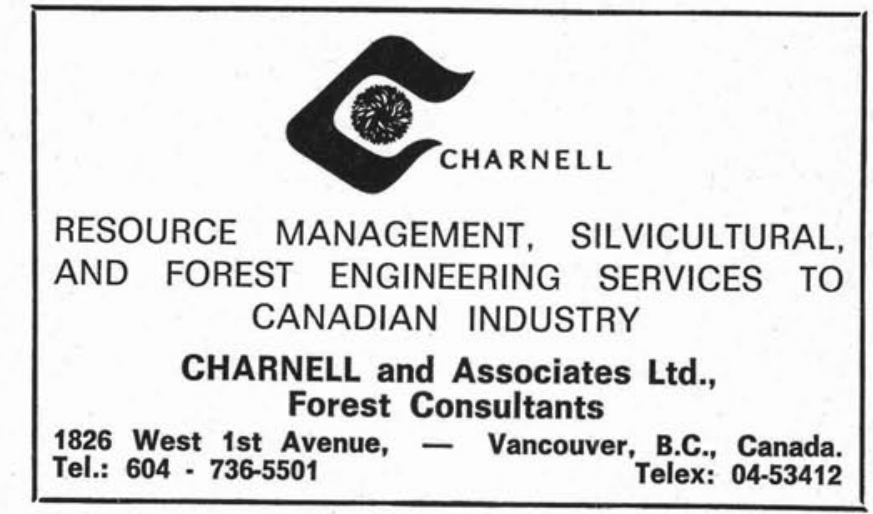

